\title{
Impact of the coronavirus disease-19 pandemic on electrophysiological procedures at a national referral center
}

\section{Impacto de la pandemia de COVID-19 en procedimientos electrofisiológicos en un centro de referencia nacional}

\author{
Angel Cueva-Parra, Guillermo Muñoz-Benavides, José A. Fernández-Domenech, \\ Jorge Gómez-Flores, Moisés Levinstein, José L. Morales', Manlio F. Márquez, \\ Pedro Iturralde-Torres y Santiago Nava* \\ Department of Electrophysiology, Instituto Nacional de Cardiología Ignacio Chávez, Mexico City, Mexico
}

\begin{abstract}
Introduction: The coronavirus disease (COVID-19) pandemic has generated serious repercussions on the health system, reducing the number of all cardiology procedures worldwide. Objectives: Describe the impact of the COVID-19 pandemic on the procedures performed by the electrophysiology department in a national referral center. Methods: We made a retrospective review of our data base and we compared procedures made in the past 3 years since 2017-2019 with the procedures made in the 2020. We divided the procedures into two large groups: Cardiac Implantable Electronic Devices (CIED) related procedures and electrophysiological procedures (EP) which included conventional and complex ablations. Results: There was a significant reduction in all the procedures, the average of procedures performed in the last 3 previous years was 467 , while in 2020, we performed only $319(p=0.01)$; this represents a reduction of $33.4 \%$ in the total number of procedures. There was no statistical difference regarding the CIED related procedures, the average of procedures in the past 3 previous years was 174 , and in 2020 we performed 190 procedures $(p=0.46)$. Regarding the $E P$, the average of the past 3 previous years was 293 , while in 2020 , we performed only 129 procedures $(p<0.01)$. The reduction in the EP was $55.97 \%$. The most affected months were April, May, and June. Conclusions: The COVID-19 pandemic considerably affected the number of the procedures in our center, reducing it by $33.4 \%$. The reduction of procedures fundamentally affected the ablations, with a reduction of $55.97 \%$. The number of CIED related procedures was not affected.
\end{abstract}

Key words: Coronavirus disease-19 pandemic. Electrophysiological procedures. Cardiac implantable electronic devices related procedures.

\section{Resumen}

Introducción: La pandemia de COVID-19 ha generado graves repercusiones en el sistema de salud, reduciendo el número de todos los procedimientos cardiológicos a nivel mundial. Objetivos: Describir el impacto de la pandemia COVID-19 en los procedimientos realizados por el departamento de electrofisiología en un centro de referencia nacional. Métodos: Realizamos

E-mail: santiagonavat@ hotmail.com license (http://creativecommons.org/licenses/by-nc-nd/4.0/).

Available online: $24-08-2021$ Arch Cardiol Mex. 2021;91(Supl):34-39 www.archivoscardiologia.com
article under the CC BY-NC-ND 
una revisión retrospectiva de nuestra base de datos y comparamos los procedimientos realizados en los últimos 3 años desde 2017 a 2019 con los procedimientos realizados en el 2020. Dividimos los procedimientos en dos grandes grupos: Procedimientos relacionados a dispositivos electrónicos implantables cardíacos y procedimientos electrofisiológicos que englobó ablaciones convencionales y complejas. Resultados: Hubo una reducción significativa en todos los procedimientos, el promedio de procedimientos realizados en los 3 últimos años previos fue de 467, mientras que en 2020 realizamos solo 319 ( $p=0.01)$; esto representa una reducción del 33.4\% en el número total de procedimientos. No hubo diferencia estadísticamente significativa con respecto a los procedimientos relacionados con dispositivos cardiacos electrónicos, el promedio de procedimientos de los 3 últimos años previos fue de 174, y en 2020 realizamos 190 procedimientos $(p=0.46)$. En cuanto a los estudios electrofisiológicos, la media de los 3 últimos previos fue de 293, mientras que en 2020 realizamos solo 129 procedimientos $(p<0.01$ ). La reducción de estudios electrofisiológicos fue del 55.97\%. Los meses más afectados fueron abril, mayo y junio. Conclusiones: La pandemia de COVID-19 afectó considerablemente el número de procedimientos en nuestro centro, reduciéndolo en un 33.4\%. La reducción de procedimientos afectó fundamentalmente a las ablaciones, con una reducción del 55.97\%. El número de procedimientos relacionados con dispositivos cardiacos electrónicos no se vio afectado.

Plabras clave: Pandemia de COVID-19. Procedimientos electrofisiológicos. Procedimientos relacionados con dispositivos electrónicos implantables cardíacos.

\section{Introduction}

Infection with the novel coronavirus (severe acute respiratory syndrome coronavirus 2 [SARS-CoV-2]) produces the 2019 novel coronavirus disease (COVID-19), on March 11, 2020, COVID-19 was declared a global pandemic ${ }^{1}$. The pandemic has produced important repercussions in the health services. Around the world, the conversion of a significant number of hospitals into COVID-19 centers and social confinement have limited the access to health services for patients with cardiovascular diseases ${ }^{2}$.

The National Institute of Cardiology "Ignacio Chávez" is a hospital specialized in the management of all types of cardiovascular diseases, however, due to the impact of the pandemic in Mexico it had to become a COVID-center ${ }^{3}$. This resulted in the fact that for some months in our Institution only cardiovascular emergencies were treated.

The Institute's electrophysiology department performs more than 400 procedures per year; most of them are patients recruit in the outpatient clinic being elective or semi-urgent procedures. During the first wave of the pandemic in Mexico, our department dedicated itself exclusively to attending emergencies and conducting teleconsultation for moderate or high-risk patients. For this reason, we have written this article with the intention of analyzing the impact of the pandemic on the procedures carried out by our department.

\section{Materials and Methods}

\section{Procedures}

We made a retrospective review of our data base since 2017-2020, for each year we perform a count of the procedures performed (in both children and adults). We divided the procedures into two groups: Cardiac Implantable Electronic Devices (CIED) related procedures (which included device implants, system revisions, changes, upgrades, and extractions) and electrophysiological procedures (EP) (which included conventional studies and complex ablations). Other types of procedures were no included in the study.

\section{Statistical analysis}

We determine the total of procedures, CIED related procedures and EP for each year. To make our findings significant, we decided to make a comparison between the procedures of the year 2020 with the average of the 3 previous years (2017-2019). Statistical analysis was performed to determine whether there was a significant difference between the 2020 procedures and the average of the previous 3 years. We analyze the trend of procedures month by month and employed the Student's t-test.

\section{Results}

\section{Total of procedures}

Total procedures in 2017 were 479, in 2018 were 411, and in 2019 were 511 . The average of procedures made were 467 , while in 2020 , we performed only 319 . There was a significant reduction in all procedures (467 vs. $319, p=0.01$ ); this represents a reduction of $33.4 \%$ in the total number of procedures performed in our center (Table 1 and Fig. 1). 


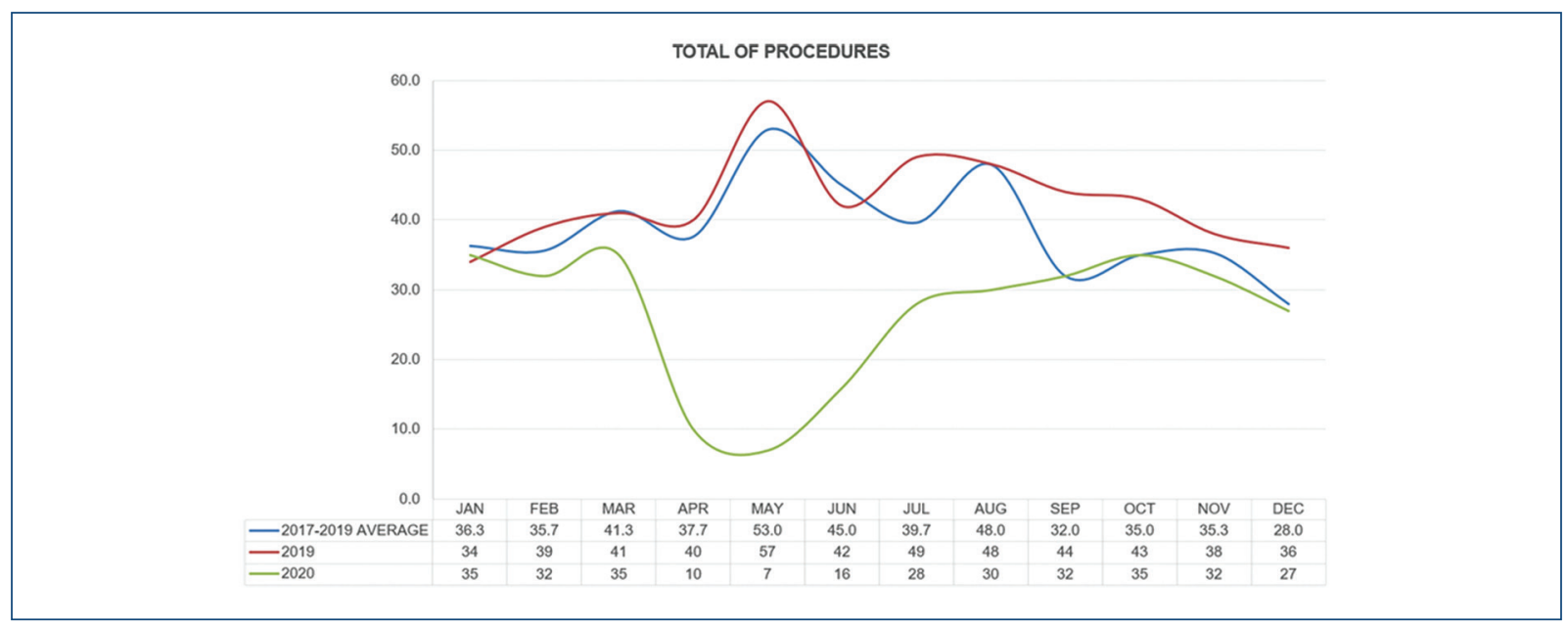

Figure 1. Graphic representation of the total procedures of the average 2017-2019, the year 2019 and 2020. Note that in 2020 the most affected months were April, May, and June.

Table 1. Total procedures performed per each year and comparison between the average 2017 and 2019 with 2020

\begin{tabular}{|l|c|c|c|c|c|}
\hline \multicolumn{7}{|c|}{ All procedures } \\
\hline Month & $\mathbf{2 0 1 7}$ & $\mathbf{2 0 1 8}$ & $\mathbf{2 0 1 9}$ & $\mathbf{2 0 1 7 - 2 0 1 9}$ average & $\mathbf{2 0 2 0}$ \\
\hline January & 40 & 35 & 34 & 36.3 & 35 \\
\hline February & 36 & 32 & 39 & 35.7 & 32 \\
\hline March & 47 & 36 & 41 & 41.3 & 35 \\
\hline April & 32 & 41 & 40 & 37.7 & 10 \\
\hline May & 62 & 40 & 57 & 53.0 & 7 \\
\hline June & 49 & 44 & 42 & 45.0 & 16 \\
\hline July & 33 & 37 & 49 & 39.7 & 28 \\
\hline August & 53 & 43 & 48 & 48.0 & 30 \\
\hline September & 23 & 29 & 44 & 32.0 & 32 \\
\hline October & 31 & 31 & 43 & 35.0 & 35 \\
\hline November & 42 & 26 & 38 & 35.3 & 32 \\
\hline December & 31 & 17 & 36 & 28.0 & 27 \\
\hline Total & 479 & 411 & 511 & $467.0 *$ & $329 *$ \\
\hline Sifican & & & & & \\
\hline
\end{tabular}

${ }^{*}$ Significant difference.

It is observed that in 2020 the most affected months were April, May, and June, months in which precisely Mexico City was in a health emergency. And from the months of September onwards, we increased the number of procedures to a level similar to the average of the previous 03 years.

\section{CIED related procedures}

In 2017, there were 186 CIED related procedures, 148 in 2018, and 188 in 2019. The average of procedures made were 174 . In 2020, we performed 190 procedures, near to the average of the previous 3 years and very close to the number in 2019 , with no statistical difference $(p=0.46)$.

Even though we did not observe differences between 2020 and previous years, an important phenomenon is observed. Fewer procedures were performed in April and May, but after those months the number of procedures increased even above the average of the previous 3 years, which made it possible to compensate the deficit of the previous months (Table 2 and Fig. 2).

\section{Electrophysiological studies and ablations}

Regarding the electrophysiological studies and ablations, the number of procedures in 2017 was 293, in 2018 was 263, and in 2019 was 323 . The average of these 3 years was 293, while in 2020 we performed only 129 procedures, considerably lower than the average of the previous years $(p<0.01)$. The reduction in the total number of EP studies and ablations was $55.97 \%$.

It is interesting to note that since the beginning of the year the number of procedures in 2020 was already lower compared to the average of previous years. The months most affected were May, June, and July. After those months, we progressively increased the number 


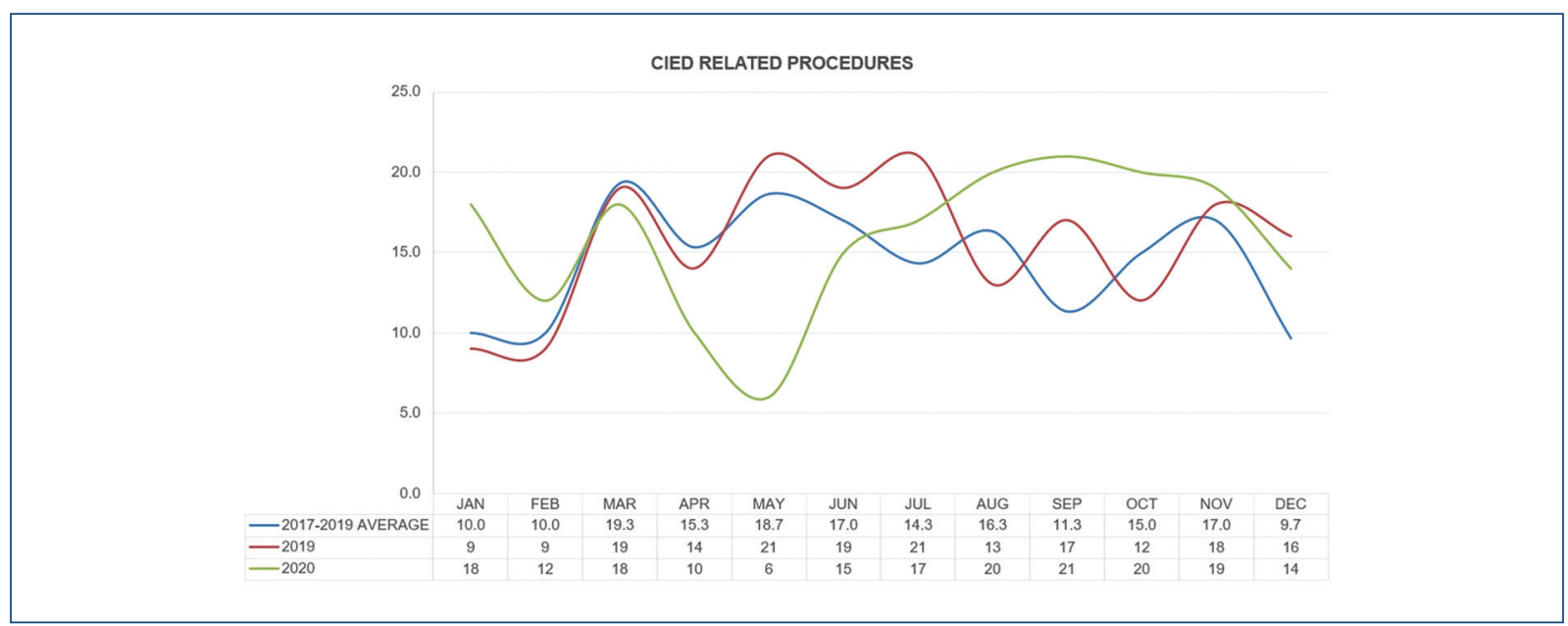

Figure 2. Graphic representation of the CIED related procedures of the average 2017-2019, 2019, and 2020. Note that the most affected months were April, May, and June.

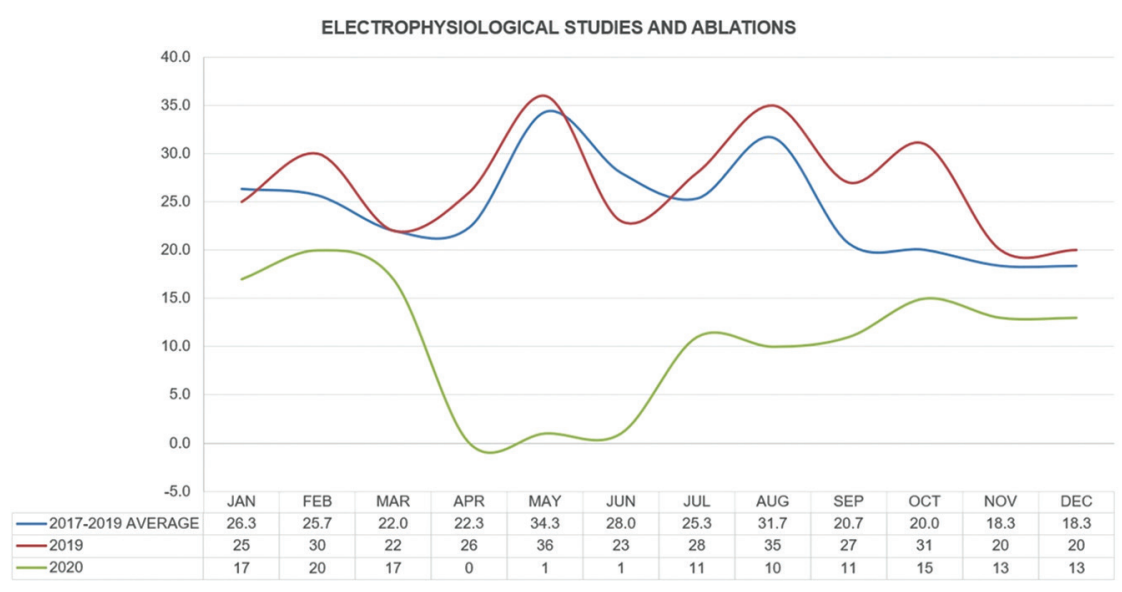

Figure 3. Graphic representation of the EP of the average 2017-2019, 2019m and 2020. Procedures performed in 2020 did not reach the average of the previous years.

of EP; however, this was not enough to compensate for the deficit of the previous months (Table 3 and Fig. 3).

\section{Discussion}

The pandemic caused the conversion of many hospitals into COVID-19 centers, in Mexico the National Institute of Cardiology "Ignacio Chávez" was no exception $^{3}$. This led to the cancellation of the outpatient clinic and various departments taking special measures. On the other hand, the operation of the hemodynamic room in our center was reserved for emergency procedures or for cases where the procedure had a direct impact on the life of the patient.

One of the first actions of our department was the creation of a management protocol for patients with COVID-19 who required medications that prolonged QT interval such as hydroxychloroquine and azithromycin ${ }^{4}$. We also carried out telephonic consultation to high-risk patients, such as those with a diagnosis of channelopathy or carriers of implantable cardiac devices such as ICDs or those with pacemakers with advanced longevity.

The pandemic also produced a significant reduction in emergency admissions ${ }^{5}$, in our institution there was a 
Table 2. CIED related procedures for each year. There was no statistical difference between the 2020 and the average of the 3 previous year

\begin{tabular}{|l|c|c|c|c|c|}
\hline \multicolumn{7}{|c|}{ CIED related procedures } \\
\hline Month & $\mathbf{2 0 1 7}$ & $\mathbf{2 0 1 8}$ & $\mathbf{2 0 1 9}$ & $\mathbf{2 0 1 7 - 2 0 1 9}$ Average & $\mathbf{2 0 2 0}$ \\
\hline January & 11 & 10 & 9 & 10.0 & 18 \\
\hline February & 13 & 8 & 9 & 10.0 & 12 \\
\hline March & 25 & 14 & 19 & 19.3 & 18 \\
\hline April & 16 & 16 & 14 & 15.3 & 10 \\
\hline May & 21 & 14 & 21 & 18.7 & 6 \\
\hline June & 19 & 13 & 19 & 17.0 & 15 \\
\hline July & 10 & 12 & 21 & 14.3 & 17 \\
\hline August & 23 & 13 & 13 & 16.3 & 20 \\
\hline September & 9 & 8 & 17 & 11.3 & 21 \\
\hline October & 15 & 18 & 12 & 15.0 & 20 \\
\hline November & 18 & 15 & 18 & 17.0 & 19 \\
\hline December & 6 & 7 & 16 & 9.7 & 14 \\
\hline Total & 186 & 148 & 188 & $174.0 *$ & $190 *$ \\
\hline & & & & \\
\hline
\end{tabular}

*No significant difference.

reduction of $55 \%$ in admissions to the emergency department ${ }^{6}$. There are multiple reports around the world about the impact of the pandemic in patients with myocardial infarction $2,7,8$; however, there are few reports of the impact in other areas such as electrophysiology 8,9 .

It is known that most EP are elective, and most of them are indicated to improve symptoms and reduce the rate of recurrence of arrhythmias, being few the cases where the EP can reduce mortality. For this reason, during the pandemic, initially it was decided to keep the patients with medical treatment, until there was an opportunity to return to normal functioning of the hemodynamic room.

In the months of March and April, a 59\% reduction in CIED related procedures and an $81 \%$ reduction in electrophysiological studies and ablations were reported in a hospital in Spain ${ }^{5}$. We made a comparison between the number of procedures performed in the entire year 2020 with the procedures of previous years and we found a significant reduction in all procedures at the expense of electrophysiological studies and ablations.
Table 3. Electrophysiological studies and ablations for each year. In 2020 a significant decrease in procedures compared to the previous years

\begin{tabular}{|l|c|c|c|c|c|}
\hline \multicolumn{7}{|c|}{ Electrophysiological studies and ablations } \\
\hline Month & $\mathbf{2 0 1 7}$ & $\mathbf{2 0 1 8}$ & $\mathbf{2 0 1 9}$ & 2017- 2019 Average & $\mathbf{2 0 2 0}$ \\
\hline January & 29 & 25 & 25 & 26.3 & 17 \\
\hline February & 23 & 24 & 30 & 25.7 & 20 \\
\hline March & 22 & 22 & 22 & 22.0 & 17 \\
\hline April & 16 & 25 & 26 & 22.3 & 0 \\
\hline May & 41 & 26 & 36 & 34.3 & 1 \\
\hline June & 30 & 31 & 23 & 28.0 & 1 \\
\hline July & 23 & 25 & 28 & 25.3 & 11 \\
\hline August & 30 & 30 & 35 & 31.7 & 10 \\
\hline September & 14 & 21 & 27 & 20.7 & 11 \\
\hline October & 16 & 13 & 31 & 20.0 & 15 \\
\hline November & 24 & 11 & 20 & 18.3 & 13 \\
\hline December & 25 & 10 & 20 & 18.3 & 13 \\
\hline Total & 293 & 263 & 323 & $293.0 *$ & $129 *$ \\
\hline
\end{tabular}

*Significant difference.

Although the number of procedures related to devices in 2020 remained close to the average of the previous years, this does not mean that in certain months there was not a significant reduction in these procedures. In the months of March and April, only urgent implants were performed, and the number of these implants was less than the average of the previous years.

We performed two implants in patients with a confirmed diagnosis of COVID-19, unfortunately they had a fatal outcome, and in an outpatient clinic, we attended a patient with arrhythmogenic right ventricular dysplasia and an ICD carrier who experienced an appropriate shock after the use of azithromycin. For logistical and economic reasons, not all patients with CIED from our center have home monitoring implemented. Only one distributor provides to our department with home monitoring at no additional cost and only for monitoring high voltage devices.

The reason why at the end of 2020 there was no significant difference in terms of the number of CIED related procedures compared to the previous ones, is because in our institution pacemaker implants are performed both 
by the Interventional Cardiology and by the of Electrophysiology Department, but during the pandemic most of them were performed by our department.

Although ablation is the treatment of choice for the management of arrhythmias, especially supraventricular. The conduct of our department was to maintain this group of patients with pharmacological treatment until the normal functioning of the center. Regarding the electrophysiological studies and ablations, no procedure was performed during April. In May, only one ventricular tachycardia ablation was performed in a patient with ischemic heart disease who was in an electrical storm. In June, only one ablation was performed in a patient with Wolff Parkinson White syndrome with multiple accessory pathways, very symptomatic, and refractory to medical treatment.

From June onwards, we began to carry out more procedures, some of them elective, but we never reached the average of the previous years. At the end of 2020 , we found significant differences in the number of electrophysiological studies and ablations, the global reduction of these procedures was of $55.97 \%$. Finally, it should be mentioned that another factor that may explain the significant reduction in ablations was the reduction in the number of operating hospital beds in the center, this was since many personnel (especially nurses) were reassigned to COVID-19 areas, and this generated a reduction in the hospital capacity in the floors where we used to admit our patients to whom we were going to carry out electrophysiological studies.

\section{Limitations}

First, this was a retrospective analysis. Second, we only include procedures performed by the electrophysiology department, but not others such as pacemaker implantation performed by the Interventional Cardiology Department. We also do not include procedures performed by the Emergency Department such as electrical cardioversions or placement of temporary pacemakers. Third, as we mentioned previously, only one provider offers us home monitoring, this is why the number of patients with ICDs with discharges during the pandemic is underestimated.

\section{Conclusions}

The COVID-19 pandemic considerably affected the number of the procedures performed by the electrophysiology department of our center, reducing it by $33.4 \%$. The reduction of procedures fundamentally affected the ablations, with a reduction of $55.97 \%$. The number of CIED related procedures was not affected.

\section{Funding}

None.

\section{Conflicts of interest}

None declared.

\section{Ethical disclosures}

Protection of human and animal subjects. The authors declare that no experiments were performed on humans or animals for this study.

Confidentiality of data. The authors declare that no patient data appear in this article.

Right to privacy and informed consent. The authors declare that no patient data appear in this article.

\section{References}

1. World Health Organization. WHO Director-general's Opening Remarks at the Media Briefing on COVID-19; 2020. Available from: https://www.who. int/dg/speeches/detail/whodirector-general-s-opening-remarks-at-the-media-briefing-on-covid-19---11-march-2020. [Last accessed on 2021 Jan 31].

2. Rodríguez-Leor O, Cid-Álvarez B, Ojeda S, Martin-Moreiras J, Rumoroso JR, López-Palop R, et al. Impacto de la pandemia de COVID-19 sobre la actividad asistencial en cardiología intervencionista en España. REC Interv Cardiol. 2020;2:82-89.

3. Aceituno-Melgar J, Martínez-Gutiérrez J, Baranda-Tovar F. From a cardiology institute to a COVID centre in Mexico: cardiology residents in training discuss the transformation of their cardiology institute into a COVID centre. Eur Heart J. 2020;2020:ehaa743.

4. Cueva-Parra A, Neach-De La Vega D, Ortiz-Solis W, Fernández-Domenech J, Lara-Aguilera S, Chi-Pool S, et al. Protocolo para la prevención de arritmias ventriculares en pacientes con $\mathrm{CO}$ VID-19. Arch Cardiol Mex. 2020;90:58-63.

5. Negreira Caamaño M, Piqueras Flores J, Mateo Gómez C. Impacto de la pandemia COVID-19 sobre los ingresos hospitalarios en cardiología. Med Clin (Barc). 2020;155:179-80.

6. Gaspar-Hernández J, Araiza-Garaygordobil D, Gopar-Nieto R, Martínez-Amezcua P, Arias-Mendoza A. Impact of the coronavirus disease-19 pandemic on acute cardiovascular emergencies in a third level cardiology hospital: a call for action. Rev Invest Clin. 2020;72:280-2.

7. Tam CF, Cheung KS, Lam S, Wong A, Yung A, Sze M, et al. Impact of coronavirus disease 2019 (COVID-19) outbreak on ST-segment-elevation myocardial infarction care in Hong Kong, China. Circ Cardiovasc Qual Outcomes. 2020;13:e006631.

8. Aldama G, Rebollal F, Flores X, Piñon P, Rodríguez-Leor $O$, Vázquez JM. Descenso del número de angioplastias primarias durante la pandemia y su relación con la mortalidad por COVID-19. El papel de los riesgos competitivos. Rev Esp Cardiol. 2021;74:474-6.

9. Chia PL, Tan K, Tan LW, Chin PS, Foo D. Rhythm blues in the time of coronavirus disease 2019 (COVID-19): how the cardiac electrophysiologist adapts to a viral pandemic in Singapore. J Interv Card Electrophysiol. 2020;58:269-72 